\title{
Euphoria Of Innovation: Improving The Image Or Performance Of Local Government?
}

\author{
Hilda Nurul Anggraeni ${ }^{1}$, Nita Nurliawati ${ }^{2}$, Cintantya Dara Kirana ${ }^{3}$, Hanny Octavianti ${ }^{4}$, Karmeilia \\ Nurul Azma ${ }^{5}$ \\ Politeknik STIA LAN Bandung ${ }^{12345}$ \\ \{hildanurulanggraeni88@gmail.com¹,nitanurliawati@yahoo.com², ca.darakirana@gmail.com³ \\ octaviantihanny@gmail.com ${ }^{4}$, karmeilianurul@gmail.com ${ }^{5}$ \}
}

\begin{abstract}
Innovation is a demand for every institution, both public and private sectors. For local governments, innovation is the main capital in order to survive and compete. This is stated in various policies to encourage each regional government to be more competitive in innovating. One of the policies that become a reference is the Government Regulation regarding regional innovation. As an effort to motivate and spur the creativity of local governments and see whether innovation really improves government performance or is only the image of the organization. So this study aims to see how effectively the innovation competition can lift the image or even the performance of the local government. This research method uses descriptive qualitative methods with data collection through interviews, observations and literature studies. The research focuses on the Cimahi City Regional Government as the most innovative area in Indonesia with a variety of innovations it has. The theory used is the diffusion of innovation which explains how an innovation can be communicated through certain channels. The theory of diffusion of innovation is then linked to the performance and measurement of the Regional Innovation Index (Indonesian: IID) from the Ministry of Home Affairs (Indonesian: Kemendagri). Through innovation competitions that are routinely held by the Central Government, it can improve employee performance and raise the image of the institutions.
\end{abstract}

Keywords: Innovation; Local Government; Policy.

\section{Introduction}

Innovation is on the government agenda as mandated in Law No. 23 of 2014 on Regional Government, in Chapter 386-390 which regulates the need for innovation in order to improve the performance of local government administration. As a form of elaboration of the legislation, Government Regulation Number 38 of 2017 concerning Regional Innovation is issued as an implementation guide for regional governments in implementing innovative practices in regional governance [1]. Innovation plays an important role in determining regional competitiveness, people's welfare and economic growth (World Bank, 2010).. This confirms that innovation is indeed needed in every development in the region which later the output of the innovation can be accepted by the community.

Innovation also continues to be implemented by the Cimahi City Government, which managed to be ranked in the top 5 in the Innovative Government Award (IGA) in 2019 as an innovative area in the city cluster based on an assessment from the Ministry of Home Affairs. In 2020, Cimahi City also received the 3rd national level award for the city with the Highest Competitiveness Index in Indonesia from the Ministry of Technology / National Research and Innovation Agency of the Republic of Indonesia [2]. 
Various innovations carried out by the Cimahi City Government continue to be encouraged for the realization of the quality of good governance. Cimahi city has participated several times in innovation competitions from various ministries and received awards, however the tendency of Cimahi's ranking to decline in 2020 due to innovation data entered in the Innovative Government Award from the Research and Development Agency (BPP) of Ministry of Home Affairs is relatively small, namely 43 innovations (2019) and 58 innovations (2020), while other regions are developing rapidly [3].

The number of various innovation competitions that exist make the public ask that whether it only raises the image of government or indeed the performance of government. This is the focus of this research where several innovations in regional government need to continue to be evaluated and updated. Therefore, the goal to be achieved is to see how effective innovation competition can lift the image or even performance of regional governments. This study include aspects of improving the image and performance of the Cimahi City Regional Government in implementing regional innovation, as well as how to optimize the euphoria of existing innovation through various regional innovation competitions as an innovative solution for governance in the current fast-paced era

\section{Methods}

The research methods used in this research are descriptive through qualitative approaches based on writing, oral, or visual documentation through online media. The analysis used in this research is based on the results of news analysis, articles, journals related to regional innovation policies in the Government of Cimahi City in improving the image or performance of the government. In addition, we used in-depth interview techniques as a data collection method supported by the city's diverse innovation data in the past three years. In conducting interviews, we encountered obstacles because the interviews were conducted online so it was rather difficult to find various facts and data that supported the research.

The location of the research was the Cimahi City Regional Government, by sharing or interviewing with the location of the research was the Cimahi City Regional Government, by sharing or interviewing with the Regional Development Planning Agency (Indonesian: Bappeda) of Cimahi City as the manager of Cimahi City regional innovation in participating in various competitions held by the Central Government. The theory used to strengthen the statement regarding the Image and Performance of the Cimahi City Regional Government in regional innovation is the Diffusion of Innovation which is associated with organizational performance and the Regional Innovation Index (IID) in measuring the maturity of innovation through the information system of the regional innovation index of the Ministry of Home Affairs. Index of maturity of innovation that meets general requirements and administrative requirements.

\section{Results}

\subsection{Regional Innovation and Its Regulations in Government Regulation No. 38 of 2017}

Regional innovation can be defined as a form of renewal in the implementation of regional government as mentioned in (Chapter 1) on Government Regulation number 38 of 2017. From the definition it is concluded that innovation is a process in an implementation that has novelty in governance. The purpose of regional innovation as stated in government regulation no. 38 of 
2017 is to improve the performance of regional government implementation through : (1) improving public services, (2) empowerment and community participation, and (3) incresing regional competitiveness. This is in accordance with the progress of the region which will depend on innovations made in the are [4].

In addition, in implementing innovation there are several factors that determine the success or failure of innovation. Here are some factors that can affect the success or failure of a regional innovation (Setiawan, 2018) :

a. Incompatibility of Innovation with Values or Norms That Develop in Society

This happens when the innovation that will be applied doesn't pay attention to the values and norms that apply in the local community. This condition occurs when the implementation of innovation is accepted by the government but has a negative effect on society when developed further.

b. Incomprehension of Implementing Elements

The innovation program that will be implemented must consider the ability of human resources as an implementing element.

c. Unprofessional Human Resources Management

Successful implementation of regional innovations at the beginning of its implementation, but then it could be after 1 year or 2 years when the manager's resource gets a promotion or mutation and being replaced by new employees who doesn't have knowledge about the innovation implemented, will result in inhibition of innovation.

d. Interest Barrier

This occurs when the proposed regional innovation is not in line with the interests of the relevant Regional Head.

e. Use of Large Resources

A government that is too passionate to innovate without considering the use of its resources[5].

\subsection{Parameters of Regional Innovation Indeks (IID)}

The innovation maturity index assessment parameter adopts aspects, variables and indicators from the Research and Development Agency (Indonesian: BPP) of the Ministry of Home Affairs at the Innovative Government Award (IGA). In general, the innovation index compiled by the Research and Development Agency of the Ministry of Home Affairs consists of 2 aspects, 8 variables and 36 indicators of regional innovation index.

There are 2 aspects, Aspects of Local Government Units with $40 \%$ of the value and Aspects of Innovation Units with a $60 \%$ of the value. In the aspect of local government units consists of 3 variables, institutions, human resources, the number of innovations and the innovation ecosystem. This aspect contains 16 indicators containing the profile of the city government [3].

Table 1. Aspect of Regional Government Units

\begin{tabular}{|l|l|}
\hline Variable & Indicator \\
\hline Institution & Vision and Mission * \\
\hline & R\&D Institution Level * \\
\hline & APBD on time \\
\hline & Licensing Upgrade Quality* \\
\hline Human Resources & Total Income per Capita* \\
\hline & Open Unemployment Rate* \\
\hline & $\begin{array}{l}\text { Amount of Increased } \\
\text { Investment* }\end{array}$ \\
\hline
\end{tabular}




\begin{tabular}{|l|l|}
\hline & Number of PAD Increases* \\
\hline & BPK Opinion* \\
\hline & LAKIP Achievement Value* \\
\hline & Decreased Poverty* \\
\hline $\begin{array}{l}\text { Number of Innovations } \\
\text { and } \\
\text { Ecosystems }\end{array}$ & Number of Innovations \\
\hline & $\begin{array}{l}\text { Human Development Index } \\
\text { Value* }\end{array}$ \\
\hline & Awards for Innovators \\
\hline & $\begin{array}{l}\text { Number of Research or Studies } \\
\text { that Support Innovation }\end{array}$ \\
\hline * required indicators & Roadmap SIDa \\
\hline & Source: BPP Kemendagri, 2021. \\
\hline
\end{tabular}

Aspects of innovation unit consist of 5 variables, infrastructure, output of knowledge and technology, speed of business processes, product sophistication and creative results. In the aspect of innovation unit, there are 20 indicators [3].

Table 2. Aspects of Innovation Units

\begin{tabular}{|c|c|c|}
\hline Variable & Indicator & Definition \\
\hline \multirow[t]{6}{*}{ Infrastructure } & $\begin{array}{l}\text { Regional Innovation } \\
\text { Regulations* }\end{array}$ & $\begin{array}{l}\text { Regulations that establish the } \\
\text { names of regional innovations } \\
\text { that are the operational } \\
\text { foundation of regional } \\
\text { innovation implementation }\end{array}$ \\
\hline & $\begin{array}{l}\text { Availability of Regional } \\
\text { Innovation HR* }\end{array}$ & $\begin{array}{l}\text { Number of people managing } \\
\text { innovation (last year) }\end{array}$ \\
\hline & Budget Support* & $\begin{array}{l}\text { Regional innovation budget in } \\
\text { regional revenue and } \\
\text { expenditure budget (Indonesian: } \\
\text { APBD) with initiation stages } \\
\text { (submission of ideas, meetings, } \\
\text { proposals, study writing), trials } \\
\text { (pilot projects, engineering, field } \\
\text { laboratories, and its kind), and } \\
\text { implementation (provision of } \\
\text { infrastructure, human resources } \\
\text { and services, technical guidance, } \\
\text { matters of service type). }\end{array}$ \\
\hline & Use of IT* & $\begin{array}{l}\begin{array}{l}\text { The use of IT in the } \\
\text { implementation of applied } \\
\text { innovations }\end{array} \\
\end{array}$ \\
\hline & $\begin{array}{l}\text { Technical Guidance on } \\
\text { Innovation* }\end{array}$ & $\begin{array}{l}\text { Capacity building and } \\
\text { competence of regional } \\
\text { innovation implementers }\end{array}$ \\
\hline & $\begin{array}{c}\text { Regional device } \\
\text { organization Innovation } \\
\text { Program in RKPD* } \\
\end{array}$ & $\begin{array}{l}\text { Regional device innovation has } \\
\text { been included in regional } \\
\text { development programs }\end{array}$ \\
\hline $\begin{array}{l}\text { Output of } \\
\text { Knowledge }\end{array}$ & $\begin{array}{l}\text { Innovation Actor } \\
\text { Involvement }\end{array}$ & $\begin{array}{l}\text { The participation } \\
\text { stakeholders in }\end{array}$ \\
\hline
\end{tabular}




\begin{tabular}{|c|c|c|}
\hline \multirow[t]{4}{*}{$\begin{array}{l}\text { and } \\
\text { Technology }\end{array}$} & & $\begin{array}{l}\text { implementation of regional } \\
\text { innovations }\end{array}$ \\
\hline & $\begin{array}{l}\text { Regional Innovation } \\
\text { Implementers }\end{array}$ & $\begin{array}{l}\text { Determination of regional } \\
\text { innovation implementation team }\end{array}$ \\
\hline & Innovation Network & $\begin{array}{l}\text { Number of regional devices } \\
\text { involved in the implementation } \\
\text { of innovation (in the last } 2 \text { years) }\end{array}$ \\
\hline & $\begin{array}{l}\text { Socialization of Regional } \\
\text { Innovation }\end{array}$ & $\begin{array}{l}\text { Dissemination of regional } \\
\text { innovation policy information } \\
\text { (last } 2 \text { years) }\end{array}$ \\
\hline \multirow[t]{4}{*}{$\begin{array}{l}\text { Business } \\
\text { Speed Process }\end{array}$} & $\begin{array}{l}\text { Technical Guidelines for } \\
\text { Innovation }\end{array}$ & $\begin{array}{l}\text { Basic provisions of use of } \\
\text { regional innovation in the form } \\
\text { of manual books }\end{array}$ \\
\hline & Ease of Service Information & $\begin{array}{l}\text { Ease of getting service } \\
\text { information }\end{array}$ \\
\hline & Ease of Innovation Process & $\begin{array}{l}\text { The time it takes to obtain the } \\
\text { process of using the results of } \\
\text { innovation }\end{array}$ \\
\hline & Complaint Settlement & $\begin{array}{l}\text { Complaint settlement ratio in the } \\
\text { last year }\end{array}$ \\
\hline \multirow[t]{3}{*}{$\begin{array}{l}\text { Product } \\
\text { Sophistication }\end{array}$} & Online System & $\begin{array}{l}\text { Network of procedures created } \\
\text { online (in the last } 2 \text { years) }\end{array}$ \\
\hline & Replication & $\begin{array}{l}\text { Regional innovation has been } \\
\text { replicated by other regions. }\end{array}$ \\
\hline & Speed of Innovation* & $\begin{array}{l}\text { The unit of time used to create } \\
\text { regional innovation }\end{array}$ \\
\hline \multirow[t]{3}{*}{$\begin{array}{l}\text { Creative } \\
\text { Results }\end{array}$} & The benefits of innovation* & $\begin{array}{l}\text { Number of users or beneficiaries } \\
\text { of regional innovation (last } 2 \\
\text { years) }\end{array}$ \\
\hline & Monitoring and Evaluation & $\begin{array}{l}\text { Satisfaction of implementing the } \\
\text { use of regional innovations }\end{array}$ \\
\hline & $\begin{array}{l}\text { Quality of Regional } \\
\text { Innovation* }\end{array}$ & $\begin{array}{l}\text { The quality of regional } \\
\text { innovation can be proven by } \\
\text { video application of regional } \\
\text { innovation. }\end{array}$ \\
\hline
\end{tabular}

\section{Discussion}

\subsection{The Result of Interviews with Bappeda of Cimahi City about Innovation in Cimahi City}

The analysis of this research uses data collection methods by interviewing one of the Bappeda employees of Cimahi City. There were several questions that were asked about innovations managed by Bappeda of Cimahi City. There are approximately 200 innovations owned by the city of Cimahi in the last three years. In these innovations, the Regional Apparatus Organizations (Indonesian: OPD) that innovate the most are dominated by Bappeda, Diskominfo, Dispangtan, DLH and Disdik.

Cimahi city has participated in various competitions held by the Central Government, such as IGA, BRIN. This demand of innovation appears in line with the issuance of Law No. 23 of 2014 concerning Regional Government which regulated regional innovation. When discussing innovation that will improve performance, it is necessary to discussed about the diffusion of 
innovation. The theory of diffusion of innovation was first proposed by Everett M. Rogers (Rogers, 2003: 108). "Diffusion is the process by which an innovation is communicated through certain channels over time among the members of a social system” (Rogers, 1938:5).

The main element in the process of diffusion is the dissemination of innovation, the existence of innovation, some are communicated through these channels, occur within a certain period of time, the interaction between the members of one social system (Sumadi Dilla, 2007:189). The interview was conducted with one of the employees of Bappeda Cimahi City, who explained that there was a stimulus given by the Government of Cimahi City in spreading the culture of innovation in every Regional Apparatus Organizations (Indonesian: OPD)

Performance is the final result of activities or achievements achieved by a person in carrying out his duties or work in accordance with the established standards and criteria (Robbins \& Coulter, 20005/2007; Rivai, 2005). According to Gibson (1987), the factors that affect performance, are individual, psychological, and organizational factors. There is a sub-variable of the organizational factor that most strongly influences the performance of a person, namely rewards. Rewards are benefits maintained by the leadership to attract and motivate a person's performance and achievements to achieve the leader's personal goals or organizational goals. Similarly, the Innovative Government Award held by the Ministry of Home Affairs, by rewarding the best innovations, makes Regional Apparatus Organizations (Indonesian: OPD) compete to show their innovation while achieving the goal of getting an award.

According to Dr. Elvinari Ardianto (2011: 62) image is a feeling, public self-image of a company, organization or institution, an impression that is deliberately created from an object, person or organization. Images are deliberately created to have a positive value. From this definition, an innovation can be created by an organization in order to get a positive impression and get a self-image from the public. As in the results of interview, based on Government Regulation No. 38 of 2017 concerning innovation, it is not yet required for Regional Apparatus Organizations (Indonesian: OPD) to participate in innovation competitions, but they are recommended and if it is increasingly innovative it will be appreciated by the Central Government.

Sustainability of innovation needs to be considered because it doesn't let innovation that has been made but only lasted in a few years. Maintaining the sustainability of innovation can be done by making regulations that contain the name of the position instead of the name of the individual, so that whoever the innovator then the innovation will continue. Then the available budget is able to support the sustainability of innovation and needs collaboration with various parties outside the government.

The obstacles faced by the city of Cimahi in maintaining the sustainability of innovation are partisanship or support from leaders that has not been maximized, then the organizational culture with mutations and rotations that make innovation abandoned or discontinued and less budget support in maintaining the sustainability of innovation

\subsection{Cimahi City is the Most Innovative Area in 2019}

The face of Cimahi as a city of military education, a center of trade and services, industrial areas as well as settlements and housing and a buffer area of Bandung City. Cimahi City has a strategic role and position which encourages the city's growth rate with various classic problems. Along with its progress, Cimahi has begun to be able to manage its area with various innovations that made to answer the various demands of local government implementation. It is proven that in 2019, the Government of Cimahi City received an award from the Ministry of Home Affairs as the most innovative area in Indonesia throughout 2019. Cimahi was selected 
as 1 of 10 cities with the highest regional innovation index in Indonesia. In addition, Cimahi was included in the top five of the Innovative Government Award's recipients [6].

The assessment mechanism in the Innovative Government Award (IGA) competition is seen from three things, the quantity, the quality, and the benefit aspect. This is based on five criteria of regional innovation, containing the renewal of all or part of the elements of innovation that have a beneficial impact on the region or society. Of the 109 innovations in 2019 owned by the Government of Cimahi City, 43 innovations were submitted to the Ministry of Home Affairs. After the assessment, selected 11 innovations with the highest innovation index values including Gastro Diplomacy Cireundeu, Katerpillar Hi-Park Cimahi, Unit Transfusi Darah RSUD Cibabat, Pesan Singkat Penduduk (Pesduk), Pelayanan Kependudukan One Day Service 3 in 1, Mobil Pelayanan Keliling, RW Tuntas, Penyederhanaan Perizinan Usaha, Pengembangan Sentra Susu Sapi Cipageran, Bank Sampah SAMICI dan Kader Perencana] [6].

An innovation is not only created, but still maintained sustainability for benefit in the community. In its implementation, there are indeed various challenges faced in maintaining the sustainability of these innovations. Innovation are created, sometimes only to raise the image of the agency but it doesn't always last long. If the innovation created is not continued and its sustainability is not clear, then it is certain that the innovation is only used as a tool to simply get an award. Not only from the internal, challenges can also come from the outside. As when implemented, innovations that are not acceptable to the community or there are other obstacles. Other obstacles faced in maintaining the sustainability of innovation are leadership support that has not been maximized, organizational culture with mutations and rotations that make innovations abandoned and discontinued, and lack of budget support so that innovation becomes less than optimal.

A competition is indeed one of the benchmarks for the success of an area in implementing innovations that have been made. However, it needs to be supported by the performance of human resources in the sustainability of these innovations. The many obstacles experienced by local governments are proof that innovation faces various challenges in its implementation. Therefore, an innovation needs to be an opportunity for local governments to improve the performance of their human resources, and image is only a bonus when an innovation can be rewarded

The government is reviewing the application of face-to-face learning, both in the type of mixed learning or full online learning. Every university improves the quality of online learning, especially in the process of delivering material.

\section{Conclusion}

Innovation is something that needs to be done by the Local Government in continuing the sustainability of its territory. Without innovation it is impossible for an area to compete well. The most influential thing is the contribution of regional leaders in creating innovation for their regions. Not only relying on policies, but innovation can also come from human resources and collaboration that can improve the sustainability of an innovation. Regulations that have been established by the Central Government, one of which is government regulation No. 38 of 2017 concerning regional innovation to strengthen innovation regulations.

Cimahi as an example of a region that is able to implement regional innovation. Cimahi as the innovative city that received an award from the Ministry of Home Affairs at the Innovative Government Award (IGA) in 2019. This needs to be done sustainability of existing innovations so that innovation doesn't stop. Through innovation, it is undeniable that the Regional Government can improve the image of their region as well as the performance of their human resources. 
In addition, innovation is the solution of regional problems and needs to involve various development actors, such as central and local governments, private sector, universities, communities and other non-governmental institutions.

\section{References}

[1] "Pedoman Umum Penilaian dan Pemberian Penghargaan Innovative Government Award \& Penjelasan Teknis Indikator Indeks Inovasi Daerah,” Pusat Litbang Inovasi Daerah, Badan Penelitian dan Pengembangan Kementerian Dalam Negeri, 2021.

[2] Arifin, "Cimahi Raih Predikat Kota Sangat Inovatif Pada Ajang Innovative Government Award 2020,” Pemerintah Daerah Kota Cimahi, 2020.

[3] Pemerintah Kota Cimahi, "Buku Panduan Pengisian Dan Penilaian Indeks Inovasi Daerah," Innovative Government Award, 2021.

[4] Tan.Matheos, "Kebijakan Inovasi Daerah Dalam Penyelenggaraan Pemerintahan Daerah," Rakornas Kelitbangan Pemerintahan Dalam Negeri, 2019.

[5] A.Pavita dan N.Farida, "Gaya Kepemimpinan Terhadap Lahirnya Inovasi Daerah," Jurnal Adminsitrasi Publik, Universitas Brawijaya, 2019.

[6] Dinas Komunikasi, Informatika, Kearsipan, dan Perpustakaan Kota Cimahi, "Pemerintah Kota Cimahi Raih Penghargaan Daerah Terinovatif 2019,” Berita Diskominfoarpus Kota Cimahi, 2021. 